\title{
Ferrari, Monica
}

\section{Pedagogy in the training experience of Italian secondary school teachers from} SSIS to FIT (and beyond?) (1998-2019)

Casale, Rita [Hrsg.]; Windheuser, Jeannette [Hrsg.]; Ferrari, Monica [Hrsg.]; Morandi, Matteo [Hrsg.]: Kulturen der Lehrerbildung in der Sekundarstufe in Italien und Deutschland. Nationale Formate und 'cross culture'. Bad Heilbrunn : Verlag Julius Klinkhardt 2021, S. 113-129. - (Historische Bildungsforschung)

Quellenangabe/ Reference:

Ferrari, Monica: Pedagogy in the training experience of Italian secondary school teachers from SSIS to FIT (and beyond?) (1998-2019) - In: Casale, Rita [Hrsg.]; Windheuser, Jeannette [Hrsg.]; Ferrari, Monica [Hrsg.]; Morandi, Matteo [Hrsg.]: Kulturen der Lehrerbildung in der Sekundarstufe in Italien und Deutschland. Nationale Formate und 'cross culture'. Bad Heilbrunn : Verlag Julius Klinkhardt 2021, S. 113-129 - URN: urn:nbn:de:0111-pedocs-225817 - DOI: 10.25656/01:22581

https://nbn-resolving.org/urn:nbn:de:0111-pedocs-225817

https://doi.org/10.25656/01:22581

in Kooperation mit / in cooperation with:

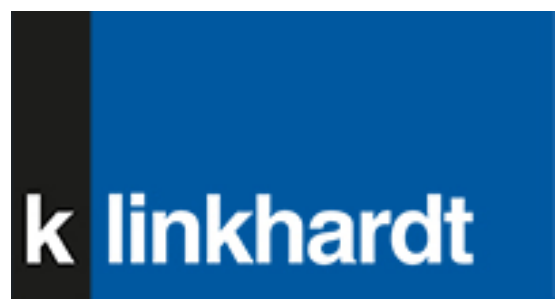

http://www.klinkhardt.de

\section{Nutzungsbedingungen}

Dieses Dokument steht unter folgender Creative Commons-Lizenz: http://creativecommons.org/licenses/by-nc-nd/4.0/deed.de - Sie dürfen das Werk bzw. den Inhalt unter folgenden Bedingungen vervielfältigen, verbreiten und öffentlich zugänglich machen: Sie müssen den Namen des Autors/Rechteinhabers in der von ihm festgelegten Weise nennen. Dieses Werk bzw. dieser Inhalt darf nicht für kommerzielle Zwecke verwendet werden und es darf nicht bearbeitet, abgewandelt oder in anderer Weise verändert werden.

Mit der Verwendung dieses Dokuments erkennen Sie die Nutzungsbedingungen an.

\section{Terms of use}

This document is published under following Creative Commons-License: http://creativecommons.org/licenses/by-nc-nd/4.0/deed.en - You may copy, distribute and transmit, adapt or exhibit the work in the public as long as you attribute the work in the manner specified by the author or licensor. You are not allowed to make commercial use of the work or its contents. You are not allowed to alter, transform, or change this work in any other way.

By using this particular document, you accept the above-stated conditions of use.

\section{Kontakt / Contact:}

\section{peDOCs}

DIPF | Leibniz-Institut für Bildungsforschung und Bildungsinformation Informationszentrum (IZ) Bildung

E-Mail: pedocs@dipf.de

Internet: www.pedocs.de

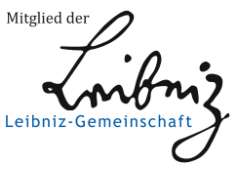




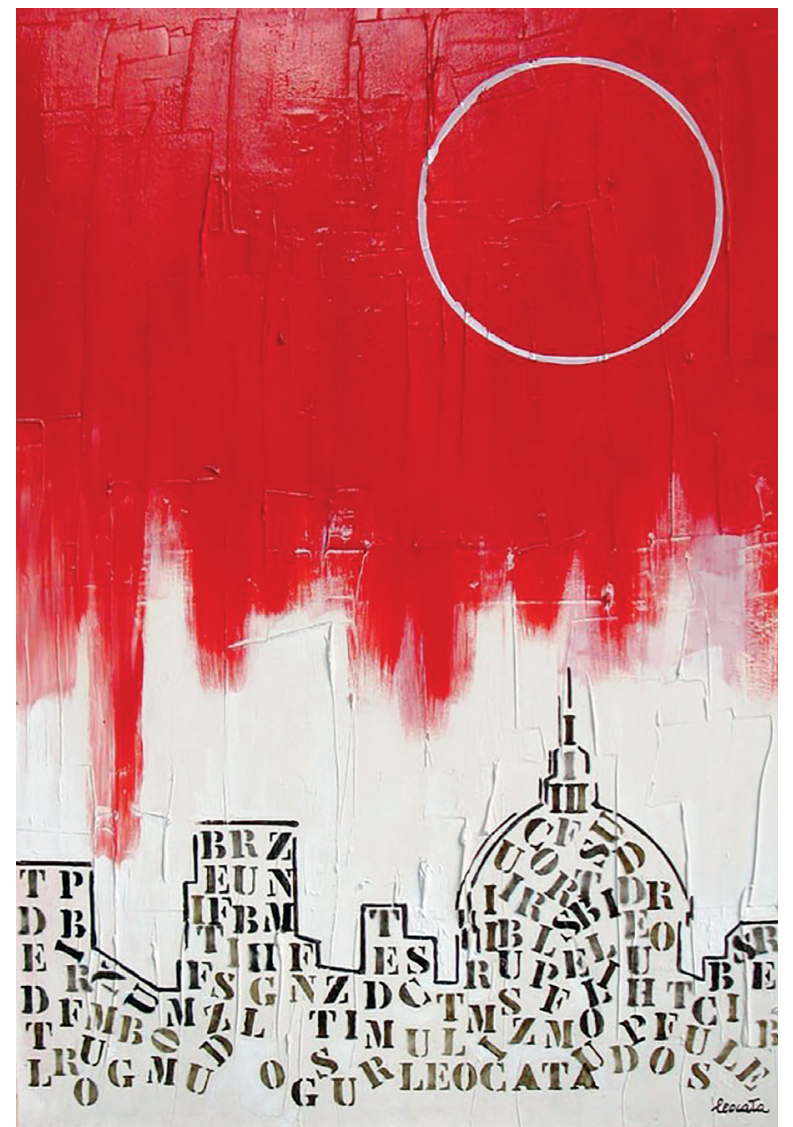

Rita Casale / Jeannette Windheuser Monica Ferrari / Matteo Morandi (Hrsg.)

\section{Kulturen der Lehrerbildung in der Sekundarstufe in Italien und Deutschland}

Nationale Formate und ,cross culture، 
Casale / Windheuser / Ferrari / Morandi

Kulturen der Lehrerbildung in der Sekundarstufe in Italien und Deutschland 


\section{Historische Bildungsforschung}

herausgegeben von

Rita Casale, Ingrid Lohmann und Eva Matthes

\section{In dieser Reihe sind erschienen}

Vogt, Michaela: Professionswissen über Unterstufenschüler in der DDR. Untersuchung der Lehrerzeitschrift „Die Unterstufe“ im Zeitraum 1954 bis 1964. Bad Heilbrunn 2015.

Heinemann, Rebecca: Das Kind als Person. William Stern als Wegbereiter der Kinder- und Jugendforschung 1900 bis 1933. Bad Heilbrunn 2016.

Conrad, Anne/Maier, Alexander (Hrsg.): Erziehung als ,Entfehlerung'. Weltanschauung, Bildung und Geschlecht in der Neuzeit. Bad Heilbrunn 2017.

Müller, Ralf: Die Ordnung der Affekte. Frömmigkeit als Erziehungsideal bei Erasmus von Rotterdam und Philipp Melanchthon. Bad Heilbrunn 2017.

Zimmer, Eva: Wandbilder für die Schulpraxis. Eine historisch-kritische Analyse der Wandbildproduktion des Verlags Schulmann 1925-1987. Bad Heilbrunn 2017.

Horn, Elija: Indien als Erzieher. Orientalismus in der deutschen Reformpädagogik und Jugendbewegung 1918-1933. Bad Heilbrunn 2018.

Haupt, Selma: Das Beharren der Rektoren auf die „Deutsche Universität“. Bad Heilbrunn 2018. Wehren, Sylvia: Erziehung - Körper - Entkörperung. Forschungen zur pädagogischen Theorieentwicklung. Bad Heilbrunn 2020. 


\section{Rita Casale Jeannette Windheuser Monica Ferrari Matteo Morandi \\ (Hrsg.)}

\section{Kulturen der Lehrerbildung in der Sekundarstufe in Italien und Deutschland}

Nationale Formate und ,cross culture 
Der vorliegende Band konnte mithilfe der finanziellen Unterstützung des Lehrstubls für Allgemeine Erziehungswissenschaft / Theorie der Bildung der Bergischen Universität Wuppertal veröffentlicht werden.

Aufgrund einer Vereinbarung zwischen den beiden Verlagen, die die gegenseitige freie Verfügbarkeit der Vertriebsrechte festlegt, erscheint dieser Band zeitgleich in Italien im Verlag FrancoAngeli, herausgegeben von M. Ferrari, M. Morandi, R. Casale und J. Windheuser, unter dem Titel La formazione degli insegnanti della secondaria in Italia e in Germania. Una questione culturale.

Die Herausgeber*innen bedanken sich bei dem Künstler Pippo Leocata für die kostenfreie Überlassung des Titelbildes.

Dieser Titel wurde in das Programm des Verlages mittels eines Peer-Review-Verfahrens aufgenommen. Für weitere Informationen siehe www.klinkhardt.de.

Bibliografische Information der Deutschen Nationalbibliothek Die Deutsche Nationalbibliothek verzeichnet diese Publikation in der Deutschen Nationalbibliografie; detaillierte bibliografische Daten sind im Internet abrufbar über http://dnb.d-nb.de.

2021.lg. ( ) by Julius Klinkhardt.

Grafik Umschlagseite 1: () by Pippo Leocata, La città delle parole [Die Stadt der Worte], Öl und Acryl auf Leinwand, 2014. (Privatsammlung)

Druck und Bindung: Bookstation GmbH, Anzing.

Printed in Germany 2021.

Gedruckt auf chlorfrei gebleichtem alterungsbeständigem Papier.

Die Publikation (mit Ausnahme aller Fotos, Grafiken und Abbildungen) ist veröffentlicht unter der Creative Commons-Lizenz: CC BY-NC-ND 4.0 International https://creativecommons.org/licenses/by-nc-nd/4.0/ 


\section{Inhaltsverzeichnis}

\section{Einführung}

Nationale Fälle und cross culture in der Lehrerbildung

Rita Casale, Monica Ferrari, Matteo Morandi und Jeannette Windheuser .7

\section{Italien}

Habsburg Legislation on the Training of Elementary and Ginnasio-Liceo (Secondary) Teachers and its Implementation in the Italian Territories across the $18^{\text {th }}$ and $19^{\text {th }}$ Centuries

Simonetta Polenghi

The Scuola Normale Superiore di Pisa: between French Model and Autonomous Choices (1810-1923)

Paola Carlucci und Mauro Moretti

Long-Term Issues in Secondary School Teacher Training in Italy

(1862-2015)

Matteo Morandi

Belgium as a Cultural Model for Building the Italian Secondary School and Training its Teachers (1860-1900)

Mara Donato di Paola

An Atypical Path of Women Teachers Training, between the $19^{\text {th }}$ and $20^{\text {th }}$ Centuries: the Istituti Superiori di Magistero femminile

(Higher Institutes of Teaching for Women)

Tiziana Pironi

The Professor of Pedagogy and Italian Textbooks between the $19^{\text {th }}$ and the $20^{\text {th }}$ Centuries

Giuseppe Zago

Pedagogy in the Training Experience of Italian Secondary School Teachers

from SSIS to FIT (and beyond?) (1998-2019)

Monica Ferrari

Training Secondary-School Teachers and the Position of the Minor.

Reflections from a Juridical-Constitutional Perspective

Giuditta Matucci 
The Role of Pedagogy in the Initial Training of Teachers of the Italian Secondary School Today Anna Bondioli, Maurizio Piseri und Donatella Savio

\section{Deutschland}

Seminare - eine hybride Ausbildungsform (18. bis 19. Jahrhundert)

Sabine Reh und Joachim Scholz

Gymnasiallehrer im Vormärz (1830-1848):

Zwischen Wissenschaft und Lehrberuf

Margret Kraul

Geisteswissenschaftliche Pädagogik und

höhere Lehrerausbildung (1915-1960)

Eva Matthes

Modernisierung durch Feminisierung? Zur Geschichte der

Lehrerinnenbildung in Deutschland (19. und frühes 20. Jahrhundert)

Elke Kleinau

Die Lehrerausbildung in der Bundesrepublik seit 1990: die Gründung

der Schools of Education

Charlotte Röhner

Die Entpädagogisierung der Lehrerbildung in der Bundesrepublik und die Entstehung der Bildungswissenschaft als Leitdisziplin in den 1990er Jahren

Rita Casale

Zur Heterogenität des Lehramtsstudiums in Deutschland:

Interaktionsanalysen universitärer Lehrkulturen (21. Jahrhundert)

Imke Kollmer, Hannes König, Thomas Wenzl und Andreas Wernet

Sexuelle Bildung: Geschichtliche und curriculare Perspektiven in der Lehrer/innenbildung

Julia Kerstin Maria Siemoneit und Jeannette Windheuser

Entwicklungen der Lehrerbildung in Deutschland

Jürgen Oelkers 


\title{
Pedagogy in the Training Experience of Italian Secondary School Teachers from SSIS to FIT (and beyond?) (1998-2019)
}

\author{
by Monica Ferrari
}

To understand the role of pedagogy in the pre-service training of teachers of Italian secondary schools from SSIS $(1998)^{1}$ - an absolute novelty in the Italian panorama of post-graduate training - to TFA ${ }^{2}$ which followed the decommissioning of SSIS in 2008 (and beyond), up to today's debate, it is necessary first of all to retrace the process of the regulatory provisions.

In his 2001 book, entitled Insegnare a insegnare. I nuovi corsi universitari per la formazione dei docenti, ${ }^{3}$ Giunio Luzzatto sums up the long journey that led to the 1998 decree $^{4}$ and speaks of 'a wait that lasted over a century' for the training of Italian school teachers. The process of school autonomy, which started between 1997 and 1999, is directly connected to a series of regulatory measures that significantly altered the balance of the relationship between universities and schools. Heir to the Scuola Normale launched by the Casati law of 1859, which from 1923 onward trained teachers to enter, after a concorso (competitive state exam), primary schools, the teacher-training schools closed in 1998. This marked the birth of the degree course in primary education sciences. Moreover, ISEF, ${ }^{5}$ which from 1952 have trained those destined to becoming physical education teachers, ${ }^{6}$ was closed down; it was replaced by degree course in Sports Science (see Legislative Decree 8 May 1998, n. 178). In 1999, in decree 3 November 1999, n. 509, MURST (Ministero dell'Università e della Ricerca Scientifica e Tecnologica Ministry of University and Scientific and Technological Research) ${ }^{7}$ published the Regulation setting out the rules concerning the didactic autonomy of universities. ${ }^{8}$

But it is the MURST Decree (along with the MPI - Ministry of Public Education) of 26 May 1998, General criteria for the regulation by universities of the systems of primary education science degree courses and of secondary teaching specialisation schools (Prodi I Government), ${ }^{9}$ that is the starting point of the subject treated here, which is related to the role of pedagogy in the training of Italian secondary school teachers.

I would like to specify that, given the complexity of the different questions intertwined in the complicated picture of the history of secondary schools in Italy, ${ }^{10}$ I will not deal with the train-

1 Scuole di Specializzazione all'Insegnamento Secondario - Secondary Teaching Training Schools.

2 Tirocinio Formativo Attivo - Active Training Apprenticeship.

3 Luzzatto 2001. On the training of teachers in Italy, see Santoni Rugiu/Santamaita 2011.

426 May 1998, Minister of Education and University and of Scientific and Technological Research, Luigi Berlinguer - Prodi I Government.

5 Istituto Superiore di Educazione Fisica: see Law, 7 February 1958, n. 88 in Gazzetta ufficiale della Repubblica italiana, 6 March 1958, n. 57.

6 See Ferrari/Morandi 2015.

7 These are years of rapid change, including for the name of the Ministry.

8 In Gazzetta ufficiale della Repubblica italiana, 4 January 2000, n. 2.

9 In Gazzetta ufficiale della Repubblica italiana, 3 July 1998, n. 153.

10 See Morandi 2014; Ricuperati 2015. Regarding specific matters of school law in the context of the evolution of the Italian school system, see Falanga 2017. 
ing of educational assistants nor with the teacher recruitment methods, both through concorso (in the past both with or without entrance prerequisites and with the various denominations and configurations in recent years $)^{11}$ and through the inclusion in ranking lists. I will only reflect on the pre-service training that has enabled since 1998 the qualification ('abilitazione') of teachers with specific subject certifications in the first- and second-level secondary school. In particular, I will discuss the encyclopaedia of educational sciences evoked in the regulatory provisions related to the initial training of secondary school teachers.

\section{1998: new perspectives for the teacher figure in the SSIS}

The Formative objective of the degree course and of the school (appendix A), School's minimum qualifying contents (appendix C)) and Establishment of the school's fields of study (appendix D) are extremely important when trying to understand the change that occurred at the level of regulatory provisions.

The 'professional profile' of teachers in the degree course and specialisation school is discussed in appendix A. This is the first time in the history of the Italian educational system that the training of primary and secondary school teachers was placed on equal terms, thus recognising their common educational function regardless of school level. After the 'knowledge regarding the disciplinary sector', the second point deals with the ability to listen to pupils:

'2. Listening, observing, understanding pupils during educational activities, taking on consciously and collectively their educational and psychosocial needs in order to promote building of personal identity, female and male, along with self-orientation'.

This article (2) is sufficient to understand the role of different forms of pedagogical knowledge evoked in this document that brings into play the whole encyclopaedia of educational sciences, not least docimology in point 11 , intercultural pedagogy in point 12 , while disciplinary teachings are called on to interact with the didactic technologies at point 8 .

Moreover, the didactic structure of the various universities cannot disregard, according to the SSIS regulations, Area 1, training for the teaching function; Area 2, pertaining to the educational content of the various fields; Area 3 (workshop with specific reference to the educational content of the various fields); and Area 4, apprenticeship.

In particular, Area 1 'includes didactic activities aimed at the acquisition of the necessary attitudes and competencies laid down in appendix A in Educational Sciences and in other transversal aspects of the teacher function'. The explicit mention of educational sciences in this area highlights its importance in the training of secondary school teachers, even if with reference to 'other transversal aspects' that however are not stated in the Appendix A in question.

The various Italian universities then interpreted the regulations along the lines of different pedagogic-didactic projects and feasibility studies. The result was a varied and complex situation in need of a detailed examination. We can find informations on that issue not only in regulations, rules, prospectuses of single faculties and teaching programmes of the various courses, but also

11 On the subject, with particular reference to the 2016 concorso, see Bruschi 2016. To sum up, after the 1999-2000 concorso, only two other similar exams took place following the closing of SSIS: one in 2012/2013 and one in 2016. See also for a reflection on the principle of the concorso, which is the basis of recruitment in the Italian school system, Saltari 2014. At the time this book ends, in 2020, another concorso has been launched. 
in a series of publications that, in the decade following these provisions, up to the closure of the SSIS in 2008, told the story of the cultural debate and research-training experiences. ${ }^{12}$

Some of these volumes - written by people who experienced SSIS first hand in a variety of different roles (teacher, area or school coordinator, supervisor, etc.) - focus on the relationship between university and school with regard to apprenticeship, ${ }^{13}$ while other volumes treat the combination of Area 1 and subject knowledge. ${ }^{14}$ The research even goes on to monitor the SSIS experience within particular contexts, ${ }^{15}$ and specific research-training experiences, with the postgraduate trainees as protagonists, begin to be voiced. ${ }^{16}$ The will to talk about the work experience within the context of the SSIS - between research and training - emerges from various actors involved. ${ }^{17}$ Reflections on the matter and an evaluation strategy start to be outlined regarding the training provided by these schools in the various Italian faculties, ${ }^{18}$ while at the same time a complex general framework is discussed.

For the very first time in Italy, universities and secondary schools worked together on an institutionalised path for the training of teachers that required the presence of specific mediation figures between the two worlds: the supervisors. ${ }^{19}$ And for the first time, apprenticeships in all forms and designations ('direct'/'indirect', observational, theoretical etc.) were completely integrated into the training curriculum of future secondary school teachers, opening up new ways of understanding one's role at the school, both for aspiring teachers and those recruited under the old system with permanent contracts. Not only the SSIS supervisors but also many 'tenured' teachers began to ask themselves about the role they could play in supporting the apprenticeship path, while ad hoc conventions started between the secondary schools and universities. This might also explain why in these years there was no lack of research on the teachers' perceptions of their role not only at school with their pupils but also in the social sphere, not to mention in the processes of change that were ongoing. This all occurred within the framework of discussions about the teaching profession and teacher professionalism in rapidly changing contexts as well as under the institutional profile. ${ }^{20}$

Moreover, while in Italy there is a major historiographical debate on the evolution of the various professions in Europe between the modern and contemporary eras, ${ }^{21}$ at the same time ${ }^{22}$ we see a reflection on teacher professionalism. This reflection merges with sociological analyses of the change in progress and with new interests in the area of a 'pedagogical history of professions', attentive to the latent and not necessarily codified or institutional aspects of the professionalisation pathways. In this approach, the diachronic perspective allows us to grasp some aspects of the evolution of the profession and of becoming a professional educator in the social sphere, at the crossroads with other professional profiles and figures, between being and having

12 For an evaluation of the legacy of SSIS up to 2009, see Di Pasqua/Grassilli/Storti 2009.

13 See Bondioli/Ferrari/Marsilio/Tacchini 2006, also for a bibliography on the topic. The book edited by Ulivieri/ Giudizi/Gavazzi 2002 is one of the first to be published along with the one edited by Genovese 2001 and the following book: Jori/Migliore 2001.

14 See Bruscagli/Coppini 2004; Bellatalla 2005; Delfrati 2006.

15 See Balduzzi/Vannini 2008.

16 See Ferrari 2003.

17 See Di Pasqua/Grassilli/Storti 2008.

18 See Ferrari 2011; Ardizzone/Pippolo 2003.

19 See Bonetta/Luzzatto/Michelini/Pieri 2002.

20 See Lisimberti 2006; Mattioli 2009.

21 See Malatesta 2009; Festi/Malatesta 2010.

22 See Cavalli 1992; 2000; Cavalli/Argentin 2010. 
to be, among witnesses of the daily didactic practice, educational theories and legal obligations, based on different kinds of sources and relative to case studies in circumscribed contexts. ${ }^{23}$ Issued on 28 March 2003, Law n. 53 (Minister of Education, University and Research Letizia Moratti, Berlusconi II Government) ${ }^{24}$ highlights in Article 5 the unity of the teacher function among the different school degrees, a claim already posited in the 1998 measures, while stressing to an even great extent the role of apprenticeship in the initial training. ${ }^{25}$ Among other things this Law anticipated a teaching master's degree (laurea magistrale), which will never be realised, while, at the same time, among a number of other uncertainties for the future, the SSIS continue their life, de facto lacking, with regards to the university training offer, an exclusively dedicated body of teachers.

We should also not to forget that the story of the SSIS overlaps with other stories, such as that of the special qualifying training, realised pursuant to the dispositions of Law 143/2004 (Art. 2, paragraph $1 \mathrm{c}$ bis and ter) and regulated by the Ministerial Decree $85 / 2005$. This was a training course addressed to teachers of all levels who lacked the formal teaching qualification but who had the period of service requirement equal to 360 days. In a ministerial circular letter addressed primarily to the Rectors of the universities, and signed by the General Director of the Ministry of University and Research (prot. 2310, 18 December 2006), the dispositions regarding the timing of the organisation of the work and the conclusion of said courses were discussed, which had to take into account the possibility of using the certificate obtained in the teaching ranking lists.

\section{Between 2008 and 2010}

After the halt of SSIS as set out by Law 6 August 2008 n. $133^{26}$ (under the Berlusconi IV Government), almost two years elapsed before the issue of training Italian secondary school teachers between university and school was again addressed by Ministerial Decree 10 September 2010 n. $249 .{ }^{27}$

In the Regulation concerning: 'Definition of the regulatory framework, requirements and procedures for initial training of nursery, primary, first and second level secondary school teachers, pursuant to Article 2, paragraph 416 of law n. 244 of 24 December 2007, signed by the Minister for Education, University and Research (MIUR) of the Berlusconi Government, Mariastella Gelmini, in 2010, it is reaffirmed in Article 2 that:

'the initial teacher training referred to in Article 1 aims at nurturing the teacher function through the acquisition of disciplinary, psycho-pedagogical, methodological-didactic, organisational and relational skills necessary to allow students to reach the learning goals laid down by the current law'.

23 For a reflection on the topic, see Becchi/Ferrari 2009; for a more recent assessment of the research path and its reasons, see Becchi/Ferrari 2018.

24 In Gazzetta ufficiale della Repubblica italiana, 2 April 2003, n. 77.

25 See Montuschi 2003.

26 For an evaluation up to 2009, see Marescotti 2009; Frabboni/Giovannini 2009.

27 Published in Gazzetta ufficiale della Repubblica italiana, 31 January 2011, n. 24, Suppl. n. 23/L. 
For teaching at the first- and second-level secondary school, there is reference in Article 3, paragraph 2, letter b to 'a 2-year master's degree (corso di laurea magistrale) and a following year of active apprenticeship'.

In the decree, two bodies, established within this time frame, were recalled upon for various reasons: INVALSI (heir in 1999 of the $\mathrm{CEDE}^{28}$ ) and ANVUR. Moreover, it is no longer possible to ignore a European reference framework for basic skills. ${ }^{29}$

The scientific-disciplinary sectors of the Educational Sciences were integrated (see Art. 15, paragraph 22) with the scientific disciplinary sectors M-PED/01 (Pedagogy, Theories of Education and Social Education) and M-PED/02 (History of Pedagogy and Education). Moreover, the sector M-PED/03 (Methodologies of Teaching and Special Education) is present in the tables concerning first level secondary school. Reading the various lists (for example, number 8 concerning the qualification class A032-Music), ${ }^{30}$ it is understood that General Education, Special Needs Education and Didactics, General Didactics, and School Law are the reference subject areas of the 'basic training activities' in the 'common area'.

It is in Article 7 that the active apprenticeship (TFA) is mentioned (Art. 10) as a 'teaching preparatory course reserved to people who have obtained' a master's degree. As stated in Article 10, paragraph 3, this TFA comprises 'four groups of activities': lessons of educational sciences, indirect and direct apprenticeship, lessons in subject didactics, pedagogic-didactic laboratories. But what actually happened in the years that followed? In fact, we can see a stalemate situation in which new forms of recruitment are progressively introduced, also in the form of concorsi, effectively putting the break on the relationship between university and school that laboriously began with the SSIS and was interrupted in 2008. ${ }^{31}$ A vast cultural debate erupted which included schools, trade unions, universities, experts in public law, ${ }^{32}$ pedagogy ${ }^{33}$ and didactics (subject and not), pedagogic societies, even related journals. ${ }^{34}$ While it would be impossible to reconstruct these debates in sufficient detail here, it is worth noting that they, in my opinion, manifest the distance between the reflections offered by operators, researchers and experts and the decisions made on the matter by the various governments that succeeded one another (the Berlusconi Government, the Monti Government and, more recently, both the Renzi Government and Gentiloni Government). ${ }^{35}$

\section{The first TFA cycle (2011-2012)}

The first TFA cycle, initiated following the MIUR Decree 4 April 2011 n. 139 and signed by Mariastella Gelmini, was actually carried out in the 2012-2013 academic year. ${ }^{36}$ This was done so within the context of an uncertain regulatory framework that allowed the Active

28 On the evolution of the evaluation bodies in the Italian school system (from SNQI established in 1997 to the evolution of INVALSI since 1999), see Ferrari/Morandi/Falanga 2018, besides the INVALSI website.

29 See Capperucci 2013.

30 I am referring to page 42 of issue 24 of the Gazzetta ufficiale della Repubblica italiana, mentioned above.

31 See Saltari 2014.

32 See Matucci/Rigano 2016.

33 For a reflection on the matter that addresses the issues connected with comparative education, see Cappa/Niceforo/Palomba 2013.

34 I am thinking, purely by way of example, of the magazine of the SIRD (Italian Society of Didactic Research).

35 The Minister of Education for the Conte I Government, Marco Bussetti, then announced new measures.

36 For an evaluation and critical analysis up to 2012, see Ulivieri 2012. 
Apprenticeship (TFA) to proceed, between university and school, regardless of the qualifying master's degree already proposed.

As per the MIUR 'notice' 28 February 2013 (protocol number 0000549), there is a 'heterogeneous situation in relation to the starting time of didactic activities and the likely times of conclusion of the same'. The precariousness of the new training regime of secondary school teachers, which exists in Italy to this day, does not benefit the regular implementation of the courses that struggle each time to start. The rapid change of the reference parameters forces institutions that offer courses - primarily universities - to invent new paths and constantly find new human resources to realise them (besides restructuring the function of offices and secretariats), while the recruitment of young researchers is blocked due to the economic crisis. Looking at pedagogy, the sectors most present in this new TFA are Methodologies of Teaching and Special Education (M-PED/03) and Educational Research (M-PED/04); other sectors are relegated to the background per Ministerial Decree 249/2010 (see Table 11). Didactic methodologies and special needs education are at the centre of this Active Apprenticeship cycle, which follows a very dense work programme: the work proscribed for a period of two years under the SSIS was compressed into one - all while waiting for the programmes for the teaching master's degrees to finally commence, which in reality will never start.

In this way, the Active Apprenticeship is gradually stripped of meaning for the various social actors involved in university teaching, although it continues to force universities, schools and students to respect the imposed timing and training plan. Given the repeated changes of direction, despite a significant educational commitment to providing training, the concerns of institutions are, in my opinion, once more necessarily focussed on respecting the procedures established to start the courses and to achieve the qualification. Both the failure in systematising a path of initial training of secondary school teachers over an extended period of time and the continuous changes in direction hinder the experiences of systematic evaluation of the training plan in view of creating improvement plans shared by all the stakeholders.

\section{PAS (Percorsi Abilitanti Speciali - Special Qualifying Training): 2013-2014 and 2014-2015}

The TFA is certainly unable to solve either the problems relating to the initial training of secondary school teachers (who need to gain, over an extended period of time, experience in targeted contexts and to reflect in a scientifically savvy way on the experience) or the problems of precarious employment of Italian secondary school teachers.

In fact, the Departmental Decree 22 November 2013 n. 45 activated the PAS, pursuant to Article 15 of the Ministerial Decree 249/2010. The process of activation was as follows: on 25 March 2013 (with Ministerial Decree n. 81), ${ }^{37}$ the Minister of Education, University and Research, Francesco Profumo (Monti Government), launched the PAS (with no entrance exam), which was reserved to certain individuals pending an assessment of their conformity to the requirements. In Article 4 of the previously mentioned Regulation setting out the amendments to the Decree of 10 September 2010, n. 249, it is specified that the reference is to those individuals who, without qualification ('abilitazione'), 'have acquired, starting from school

37 In Gazzetta ufficiale della Repubblica italiana, 4 July 2013, n. 155. 
year 1999/2000 up to and including school year 2011/2012, at least three years of service in state schools, officially recognised private schools or professional training centres'.

Both Methodologies of Teaching and Special Education (M-PED/03) and Educational Research (M-PED/04) play central roles in this training programme, which pays attention to the training of teachers concerned with the educational needs of special needs students and the digital skills provided for in the recommendation of the European Parliament and of the Council of 18 December 2006. The aforementioned Departmental Decree n. 45 (22 November 2013) integrates the Ministerial Decree of 25 March 2013, underlining the difficult process of activating the ministerial regulations. However, this does not help the organisation of teaching at universities, which are always called upon at the last minute to offer courses for the post-graduate trainees so that they can obtain their diploma and thereby acquire tenure following the recruitment mechanisms, which are subject to rapid change. These courses were also offered in the following academic year, 2014-2015, which completely overlapped with the TFA. This overlap effectively doubled the effort required of the universities.

In the first few years of the new millennium, at a school which in Italy has by now become autonomous, the policy guidelines changed. The National guidelines for personalised plans of educational activities released by the Minister of Education, Letizia Moratti, in $2004^{38}$ were replaced in 2007 by the National guidelines for nursery schools, primary and lower secondary education. Curriculum guidelines, which the Minister of Public Education, Giuseppe Fioroni, ${ }^{39}$ wanted to have. In 2010, the National Guidelines for licei were passed (the Minister of Education, University and Research at the time was Mariastella Gelmini). ${ }^{40}$ In 2012 (the Minister of Education, University and Research was Francesco Profumo), the new National guidelines for the curriculum of nursery schools, primary and lower secondary education ${ }^{41}$ were released, including for first level secondary schools: TFA and PAS courses were faced with the change of the National guidelines for the curriculum, which increasingly made reference to the relevant European regulation and to the eight key skills for permanent learning (Recommendation of the European Parliament and Council, 18 December 2006), while the language of the Italian school changed with regard to different orders and levels. Among other things and not only due to the effects of the TFA and PAS pathways, educational professionals and researchers were busy discussing the numerous changes taking place in school life as well as in the teachers' initial and in-service training. In those years, due to the effect of the new measures (see Directive of 27 December 2012 and Ministerial Circular 8/2013) in the Italian schools, Special Educational Needs (BES - Bisogni Educativi Speciali) are increasingly mentioned, along with inclusion: emerging themes that are considered essential in the initial training courses.

38 Approved by the Legislative Decree 19 February 2004, n. 59, in Gazzetta ufficiale della Repubblica italiana, 2 March 2004, n. 51, Suppl. n. 31/L.

39 See Ministerial Decree 31 July 2007, in Gazzetta ufficiale della Repubblica italiana, 1 October 2007, n. 228 (Suppl. n. 198).

40 See Ministerial Decree 7 October 2010, n. 211, in Gazzetta ufficiale della Repubblica italiana, 14 December 2010, n. 291, Suppl. n. 275/L.

41 See Ministerial Decree 16 November 2012, n. 254, in Gazzetta ufficiale della Repubblica italiana, 5 February 2013, n. 30 . 


\section{The second TFA cycle: $2014-2015$}

The two decrees (16 May 2014, n. 312 and 20 June 2014, n. 487) issued by the Minister of Education, University and Research, Stefania Giannini (Renzi Government), activated the second TFA cycle. The academic credit system changed compared to the first TFA cycle and, regarding pedagogy, in addition to sectors $\mathrm{M}-\mathrm{PED} / 03$ and $\mathrm{M}-\mathrm{PED} / 04$, sectors $\mathrm{M}-\mathrm{PED} / 01$ or $\mathrm{M}-\mathrm{PED} / 02$ 'with reference to the history and law of educational institutions' were included. The history of school and educational institutions became part of the academic credit system; and even if the history of education and of pedagogical ideas were not explicitly mentioned, at least a few notions were included on contextual aspects necessary for teacher training. The teacher envisioned here is probably expected to be able to enter a hyper-complex cultural context, considering its evolution under the law, perhaps even considering the ideologies that have over time oriented the ministerial programmes/guidelines ('indicazioni') of their work (which depend also on the interpretation that the individual universities and the teachers they recruited want to give), and the ever tighter relationship with the guidelines from the European Community.

In this context, the will re-emerged to start monitoring some specific situations, for example, in Bologna, ${ }^{42}$ where an evaluative and reflective experience was carried out on the progress made to underline the strong need for an analysis of the actual training paths, didactics and educational strategies. This began under the SSIS and was subject to a significant setback due to the precariousness and randomness of the framework of teacher training between 2008 and 2015 - one that, in my opinion, is likely to invalidate a priori any attempt to plan interventions and evaluate them in view of making a significant positive impact. In other words, the initial training paths of Italian secondary school teachers change due to the effect of regulatory provisions before there is adequate time for internal improvement, that is, carrying out systematic evaluation experiences year after year.

\section{Law 107 of 13 July 2015}

But other radical changes awaited the training path of Italian school teachers. The Law enacted on 13 July 2015, n. 107, Reform of the national education and training system and authorisation for the reorganisation of the legislative provisions in force $e^{43}$ (Renzi Government), once again changed the situation created in 2008. First of all, Article 1, paragraph 114 talks about a concorso based on qualifications and exams for the recruitment with permanent contract for teaching staff. It also talks about in-service continuing education (paragraphs 121-125), giving weight to merit and teacher evaluations (paragraph 126), not to mention the introduction of a united and coordinated system including both the initial training of teachers and the procedures to access the profession' (paragraph 181, letter b, point 1).

Manuela Ghizzoni published an essay in 2017 on the initial training of secondary school teachers in a volume that discusses the issue in reference to Law 107/2015 and says: 'the system introduced by Law 107 of 2015 certainly requires specific investments, not only to operate

42 See Guglielmi/Guerra 2016.

43 Gazzetta ufficiale della Repubblica italiana, 15 July 2015, n. 162. On the subject, see Domenici 2017; for a reflection on the initial training of secondary school teachers in this regulatory frame work, see Ghizzoni 2017. 
the complex training machine, but also to pay the holders of FIT contracts and the university and school staff who will manage the training'. A fear emerged regarding the risk of non-implementation of the established path if the state does not make the necessary investments. ${ }^{44}$

\section{From January 2017 to December 2019}

In January 2017, the Gentiloni Government prepared the structure of the Legislative Decree Containing the reorganisation, adjustment and simplification of the system of initial training and of the access of secondary school teacher to make it functional to giving social and cultural value to the profession (377), which had to be discussed by the Italian Parliament. The technical-legal analysis, at the time posted online, ${ }^{45}$ that accompanied the decree drafting process, highlighted the difficulties and critical issues of the system in force relating to initial and in-service training of secondary school teachers.

Article 5, paragraph 1, letter b, of the draft of the decree in January - reiterated by Legislative Decree n. 59 enacted on 13 April 2017- ${ }^{46}$ explains what is already present in Law 107/2015: that to enter the concorso which enables access to tenure one needs to have achieved during (or after) the master's degree (laurea magistrale) (or equivalent title) 24 academic credits in anthropo-psycho-pedagogical disciplines and in the methodologies and didactic techniques specific to the sector. More precisely, Article 5 (paragraph1 letters a and b) of the Decree 59/2017 reads:

'Article 5 (access requirements). Right to access the concorso with respect to the posts of teacher referred to in Article 3, paragraph 4, letter a, is constituted by the combined possession of

a) master's or single-cycle degree, or a II level diploma of artistic, musical and dance higher education (alta formazione), or similar or equivalent qualification, in line with the recruitment fields in force at the date of convocation of the concorso;

b) 24 university or academic credits, hereinafter referred to as CFU/CFA, acquired as part of the curriculum, as additional or as extra-curricular in anthropo-psycho-pedagogical disciplines and in the methodologies and didactic techniques, anyhow guaranteeing possession of at least six credits in each of at least three of the following four disciplinary areas: pedagogy, special needs education and inclusive education; psychology; anthropology; didactic methodologies and technologies'.

While a further decree has yet to be put into effect (referenced in Article 9), in May 2017, as regards pedagogy, the disciplinary fields in evidence would seem to be the following: general education, special needs education and didactics. The Decree 59/2017 establishes an initial and recruitment path structured as follows: via the concorso (Article 5) one accesses the 'FIT contract' (of initial training, apprenticeship, placement), with 'the regional school office which the territory refers to' (Article 8). Basically, for the winners of the concorso, Article 8 establishes the subscription of an FIT contract (Initial Training, Apprenticeship, Placement): 'A

44 Ibid., p. 47.

45 At the link Http://www.camera.it.

46 Published on the Gazzetta ufficiale della Repubblica italiana,16 May 2017, n. 112, Suppl. n. 23/L: Reorganisation, adjustement and simplification of the system of initial training and of access for teachers in secondary schools in order to render it functional to the social and cultural valorisation of teaching profession, pursuant to article 1, paragraphs 180 and 181, letter b) of Law n. 107 of 13 July 2015. 
paid three-year path of initial training'. The Specialisation Course for Secondary Teaching is established in the first year of the pathway: to be able to continue, the specialisation diploma must first be obtained.

In 2017, there was a general sense of curiosity about what would happen if the FIT pathway came into being in every aspect established by the legislative decree 59/2017, for instance, regarding the educational system of the specialisation course (established by Article 9, paragraph 2) and in the concrete workings of the specialisation schools (which only existed on paper). The question also dealt with the scope of the universities' discretionary power in developing their academic plan and what resources would have to be put into play. Article 9, paragraph 2, letter a, does not clearly specify how much must be focused on secondary teaching specialisation schools relating to the first year of the contract. It mentions an organisation of 'courses of lectures, seminars and workshops for the completion of the preparation of those enrolled in the field of didactics with respect to all disciplines relating to the recruitment fields, of pedagogy, special needs education and inclusive education, of psychology, of evaluation and of school laws, aiming at the progressive acquisition of pedagogic-didactic-relational skills', as well as of a 'direct and indirect apprenticeship'. Basically, emphasis is placed on pedagogy (only generically formulated), on special needs and inclusive education (which are more clearly specified) as well as on the apprenticeship, even if there is a recovery of evaluation and school law. In the Ministerial Decree of 10 August 2017, n. 616, regarding the provisions of Legislative Decree 59/2017 (Article 17) as well as the timing of the procedures of the concorso in a transitional phase, it is possible to identify 'the disciplinary fields in which the 24 credits are to be acquired that constitute a requirement for access to the concorso'. And Article 3, paragraph 1, reads: 'the university or academic institutions involved, also in consortium or under an agreement among them, establish specific training pathways, also differentiated by recruitment fields or groups of fields, for the acquisition of the basic skills in the anthropo-psycho-pedagogical subjects and in the methodologies and didactic technologies established as access requirements to the concorso'. Article 3, paragraph 3, talks about 'formative activities and related exams for a total of 24 academic credits, coordinated in order to achieve the goals laid down in Appendix A, in relation to the contents and the educational activities referred to in Appendix B and C'. The whole document and its appendixes constantly restate, with regards to pedagogy, the fields of special needs and inclusive education, 'inclusive' being the term that most recurs in the objectives and contents of the aforementioned Appendixes A and B, which speak of knowledge to acquire and skills to obtain. A very broad framework is provided regarding crucial questions in the training of the future teacher. In my opinion, however, a detailed programme of study - that follows a structured path - over a longer period of time would be useful beyond just the acquisition of the 24 academic credits that takes place in a transitory phase to access the concorso.

Beyond the key topics touched on by the appendixes that restate the objectives and contents of the courses, it is surprising to find an indication of the objectives and contents themselves, even if broad and oriented towards inclusive education. In fact, in the 2017-2018 academic year, the universities that launched the PF24 pathways were busy analysing the extent which the existing and previous exams conform to the objectives and contents declared in the Ministerial Decree 10 August 2017 n. 616 and in its appendixes. In my opinion, and in short, there is still a need to discuss the reasons that have led to the public announcement of objectives and contents of what has become a sort of 'programme' capable to guiding the implementation of existing courses and the recognition of the validity of the previous courses in relation to the 
PF24. In particular, what gives me pause is the prescriptiveness of the formula that replaced other methods used in the past, for example, that of the 'outgoing profile' of the student/ learner (used in the case of the SSIS in 1998), or that of the coherence of the SSD (Scientific Sectors) with respect to the ongoing and previous courses, which was left completely up to regarding objectives and content - the free choice of the teachers.

In the 2017-2018 academic year, only a few months after the Ministerial Decree 10 August 2017 n. 616 was enacted, it was problematic to organise the curricular courses that were so prominently featured in the decree. Since the universities had already set their teaching offer for the coming year, it was also quite difficult to implement the mechanism required for the recognition of the existing and previous exams. Again, on 25 October 2017, with the academic year already underway, the MIUR sent universities 'clarifications regarding the acquisition of the so called ' 24 academic credits' referred to in Article 5 of the Legislative Decree of 13 April 2017, n. 59 and in the Ministerial Decree 616/2017'. For universities, this basically meant responding within a short amount of time the requests of those who had already taken anthropo-psycho-pedagogical exams and were still enrolled, or those who had graduated and either did or did not possess academic credits in those subjects, or those who were enrolled in degree courses that did not include those subjects. The range of cases was (and still is) quite broad. Making things even more difficult, these cases are situated within a regulatory framework that was being questioned by the Conte I Government in 2018.

The Budget Law of 30 December 2018 of the new government de facto cancelled the FIT. The presidents of the Italian Pedagogic Society signed a document on teacher training on 30 May 2019, and this document was sent to the MIUR on 2 June 2019. The document stressed that the concorso pubblico nazionale, as it has been conceived, 'has a seriously negative impact on the training of teachers because it eliminates apprenticeship'. It then requests 'enhancing training in the field of education sciences' within the framework of an ample and articulated initial training pathway that provides integration between theoretical aspects and apprenticeship, in the context of an overall uniform and harmonious project. Within the framework of an uncertain political situation marked by government crises and by a heated political debate, it is still not possible to foresee what will happen to the initial training of teachers of Italian secondary schools in the future. The only thing we know for certain is that on 29 October 2019, the Decree Law 126 authorised the responsible ministry to announce new concorsi for the recruitment of teachers for the first and second level secondary schools. The recently established FIT is in fact abolished.

\section{The current debate: open problems}

Italian pedagogical associations spoke out in the period following the closure of the SSIS and prior to the 2015 law, including the creation of posters, which were circulated on their websites and in specialist journals, and with open letters directed at representatives of the political world.

For instance, in 2014, the SIPED (Società Italiana di Pedagogia - Italian Society of Pedagogy) had already published on its website a document titled Rethinking school in today's society. Point 10 of this document was dedicated to the 'central' matters of a new teacher training attentive towards the construction of a dialogic and participatory learning environment. 
Three years later, on 2 February 2017, the President of the SIRD (Società Italiana di Ricerca Didattica - Italian Society of Didactic Research), Achille M. Notti, sent an e-mail to all members that included a memo presented at the Committee on Culture of the House of Representatives regarding the Delegated Decrees pertaining to law 107/2015. This document, reserving the possibility of further comments, asked the responsible agencies to insist on the topics of evaluation and docimology in teacher training, without forgetting 'a path structured at the university level' for the attainment of 24 academic credits in 'anthropo-psycho-pedagogical subjects and in didactic methodologies and technologies' - or better 'in methodologies and technologies for didactics' - so as not to give the impression that only technological methodologies mattered. On the other hand, on 4 February 2017, the President of CIRSE (Centro Italiano per la Ricerca Storico Educativa - Italian Centre for Historical Educational Research), Tiziana Pironi, sends members a letter prepared by CIRSE's board of directors and sent to the honourable Manuela Ghizzoni in relation to the draft decree concerning the ways in which teachers are trained. Here 'a strong concern' is voiced against the exclusion of the areas concerning the scientific disciplinary sector History of Pedagogy from the training pathway that would lead, both during the degree and after the prospective success in the concorso, to entering the secondary school. An urgent meeting was also called to discuss the topic.

Quite a few events occurred between 2017 and 2019.

On 16 December 2018, the President of Siped, Simonetta Polenghi, on behalf of the governing board, wrote to the MIUR Minister and other responsible figures. In confronting the challenges that our society poses to the school, she emphasised 'the absolute urgency of training in the socio-psycho-pedagogical field for all teachers employed in the educational system, in all its forms' and stressed the importance of an apprenticeship path. Finally, she asked them to preserve the 'obligatory theoretical and practical post-lauream psycho-pedagogic training for those who want to access the concorsi in order to teach'. This request has evidently not been accepted. In the meeting of 16 January 2019, the CUN (National University Council), in a recommendation addressed to the MIUR Minister, stressed that the replacement of the FIT pathway with another one in which the 'initial training and testing [is] carried out exclusively within school institutions with no interaction with the university system', arranged by the budget law 145/2018, neither safeguards the initial training of teachers nor guarantees the necessary preparation 'in the psycho-pedagogical field, in subject didactics and in the practice of teaching, within a context of effective synergy between the school and university systems'.

On 30 May 2019, the Council of pedagogical societies shared a document on the training of Italian secondary school teachers. It stresses the seriousness of the situation associated with the abolition of FIT following the 2019 budget decree and the subsequent cancellation of an apprenticeship considered fundamental to ensuring the teachers' initial training. 
Given this situation, the rapid increase in the number of manifestos calling for the reform of the school come as no surprise. ${ }^{47}$ While new conventions constantly insist on such issues, ${ }^{48}$ the discussion is on the expertise of teacher. ${ }^{49}$ Volumes are being published comparing what is happening in other countries, ${ }^{50}$ while in specific publications the discussion is focussed on initial and in-service training of teachers. ${ }^{51}$

A rich production of essays and studies - not only of a pedagogical nature - seems to have stopped for now. It accompanied the life of SSIS, and this fact enabled, in some cases, the involvement of postgraduate trainees as active parts of a cultural production that went beyond the writings required to pass the exams of the various courses or to write their final thesis.

To summarise, it is my belief that we need to reflect on and debate the actual meaning of teacher training in order to find a pathway capable of restoring the dignity and value to the teaching profession. But we also and mainly need to think about what training does, its development and that of the evaluation/self-evaluation of the teacher. The teachers (pre- and in-service) embarking on this pathway must take on an active role that, at the moment, seems to be completely absent from both the PAS/TFA and PF24/FIT programmes, which have up till now been characterised by a fragile and precarious existence. This situation is characteristic of transitory situations plagued by a constant stream of new educational mandates dependent on the activation of other educational procedures proscribed by laws issued by various governments inclined to cancelling the plans and actions of its predecessor.

Instead, teacher-training experiences need to be planned and have continuity in order to guarantee the necessary evaluation of the training as it takes place, only concrete element of research and development belonging to the training pathway and the school in their inextricable relationship. Last but not least, while in the last twenty years the debate on the necessary promotion of reflectivity in the educational act $^{52}$ has expanded internationally, ${ }^{53}$ Italy has been facing the failed activation of an apprenticeship path for secondary school teachers. Actually, a clearly articulated pathway - one coherent with the developments of the epistemology of professional practice in comparison with the experiences of education professionals in other countries - has yet to be carried out. This posits a series of questions regarding the political reasons underlying these choices and their many consequences on the social sphere both in the immediate and long term.

47 While in Italy the translations of well-known texts by foreign authors on the topic are published (e.g.: Morin 2014/2015; Goleman/Senge 2014/2016; Robinson/Aronica 2015/2016), some Italian texts were published explicitly using the term 'manifesto', and associating it to schools. For example: Rostagno 2014; Gibelli 2016. The earlier volumes presenting themselves as manifestos in this sense had already been published, and they should not be confused with a more recent literary genre made up of the volumes that are constantly published as comments to the current legislation: Brocca 2003; Perrotta 2002. See also the document L'educazione per il cambiamento. Il cambiamento per l'educazione. Manifesto per gli insegnanti del XXI secolo della conferenza "Immagine ed ethos professionale degli insegnanti", April 2014, Council of Europe, Strasbourg.

48 I mention by way of example the National SIRD convention Rapporto tra didattica e saperi disciplinari held in Milan on 1-2 December 2016. It should also not be forgotten that there is a group in the SIPED specifically interested in these issues, while articles multiply in specialised journals and in the trade union periodicals.

49 See n. 22, Vol. 16, 2016 of the magazine Form@re.

50 See Baldacci 2013; Barbieri/Gaudio/Zago 2016; Magni 2018.

51 See Vol. 15, n. 3, 2017 of the magazine Formazione \& insegnamento and Domenici 2017.

52 For just one example, see Striano 2001; Ferrari 2003; Bondioli/Ferrari/Marsilio/Tacchini 2006.

53 Also on the basis of a broader discussion on the epistemology of professional practice and training aroused, among other things, by the texts of Schön: Schön 1983/1993; Schön 1987/2006. 


\section{Sources and Literature}

\section{Published Sources}

1859: Law 13 November, n. 3725. In: Gazzetta Piemontese, 18 November 1859, n. 285 (Casati Law).

1958: Law 7 February, n. 88. In: Gazzetta ufficiale della Repubblica italiana, 6 March 1958, n. 57: 'Provisions on Physical Education'.

1998: Legislative Decree 8 May, n. 178. In: Gazzetta ufficiale della Repubblica italiana, 8 June 1998, n. 131: 'Transformation of higher education institutes for physical education and institution of faculties and degree and diploma programmes for sports science, pursuant to article 17, paragraph 115 of Law n. 127 of 15 May 1997'.

1998: Ministerial Decree (MURST - Ministry for Universities and Scientific and Technological Research, with MPI - Ministry of Public Education) 26 May. In: Gazzetta ufficiale della Repubblica italiana, 3 July 1998, n. 153: 'General criteria for the regulation by universities of the systems of primary education science degree courses and of secondary teaching specialisation schools'.

1999: Decree of the President of the Republic 8 March, n. 275. In: Gazzetta ufficiale della Repubblica italiana, 10 August 1999, n. 186, Suppl. n. 152/L: 'Regulation setting out the provisions on the autonomy of school institutions, pursuant to art. 21 of Law n. 59 of 15 March 1997’.

1999: Ministerial Decree (MURST) 3 November, n. 509. In: Gazzetta ufficiale della Repubblica italiana, 4 January 2000, n. 2: 'Regulation setting out the rules concerning the didactic autonomy of universities'.

2003: Law 28 March, n. 53. In: Gazzetta ufficiale della Repubblica italiana, 2 April 2003, n. 77: 'Act authorising the government to define general provisions on education and the essential levels of performance in education and professional training'.

2004: Legislative Decree 19 February, n. 59. In: Gazzetta ufficiale della Repubblica italiana, 2 March 2004, n. 51, Suppl. n. 31/L: 'Definition of general provisions concerning nursery schools, primary and lower secondary education, pursuant to article 1 of Law n. 53 of 28 March 2003'. Annex: National guidelines for personalised plans of educational activities in nursery school (A), primary school (B) and lower secondary school (C).

2004: Law 4 June, n. 143. In: Gazzetta ufficiale della Repubblica italiana, 5 June 2004, n. 130: 'Conversion into law, with amendments, of Decree-Law n. 97 of 7 April 2004, laying down urgent provisions on ensuring the orderly launch of the 2004-2005 academic year as well as on state and university exams'.

2005: Ministerial Decree (MIUR - Ministry of Education, University and Research) 18 November, n. 85 (Activation of special courses to obtain a teaching qualification, reserved to personnel who have worked for 360 days).

2006: MUR Notice protocol 2310, 18 December. Subject: special courses regulated by Ministerial Decree 85/2005.

2006: Recommendation of the European Parliament and of the Council of 18 December on key competences for lifelong learning. In Official Journal of the European Union, 30 December 2006, Law 394/10.

2007: Ministerial Decree (MPI) 31 July. In: Gazzetta ufficiale della Repubblica italiana, 1 October 2007, n. 228, Suppl. n. 198: 'National guidelines for nursery schools, primary and lower secondary education. Curriculum guidelines'.

2008: Law 6 August, n. 133. In: Gazzetta ufficiale della Repubblica italiana, 21 August 2008, n. 195, Suppl. n. 196/L: 'Conversion into law, with amendments, of Decree-Law n. 112 of 25 June 2008, laying down urgent provisions on economic development, simplification, competitiveness, stabilisation of public finance and tax equalisation'.

2010: Ministerial Decree (MIUR) 10 September, n. 249. In: Gazzetta ufficiale della Repubblica italiana, 31 January 2011, n. 24, Suppl. n. 23/L: Regulation concerning the: 'Definition of the regulatory framework, requirements and procedures for initial training of nursery, primary, first and second level secondary-school teachers, pursuant to article 2, paragraph 416 of Law n. 244 of 24 December 2007’.

2010: Ministerial Decree (MIUR) 7 October, n. 211. In: Gazzetta ufficiale della Repubblica italiana, 14 December 2010, n. 291, Suppl. n. 275/L.: Draft regulation setting out the 'National guidelines on the specific learning objectives relating to the lessons and activities included in the curricula for the high school courses referred to in article 10, paragraph 3 of Decree of the President of the Republic n. 89 of 15 March 2010, in relation to article 2, paragraphs 1 and 3 of the same regulation'.

2011: Ministerial Decree (MIUR) 4 April, n. 139: Implementation of Ministerial Decree n. 249 of 10 September 2010, setting out the regulations concerning: 'initial teacher training'.

2012: Ministerial Decree (MIUR) 16 November, n. 254. In: Gazzetta ufficiale della Repubblica italiana, 5 February 2013, n. 30: 'Regulation setting out national curriculum guidelines for nursery schools, primary and lower secondary education, pursuant to article 1, paragraph 4 of Decree of the President of the Republic n. 89 of 20 March 2009'. Annex: National guidelines for the curriculum of nursery schools, primary and lower secondary education. 
2012: Ministerial Directive (MIUR) 27 December: 'Intervention tools for pupils with special educational needs and territorial organisation for educational inclusion'.

2013: MIUR Notice (Department of Education and Department of Universities) protocol 0000549, 28 February.

2013: Ministerial Circular (MIUR - Department of Education) 6 March, n. 8, protocol 561: 'Ministerial Directive of 27 December 2012. Intervention tools for pupils with special educational needs and territorial organisation for educational inclusion. Operating guidelines'.

2013: Ministerial Decree (MIUR) 25 March, n. 81. In: Gazzetta ufficiale della Repubblica italiana, 4 July 2013 , n. 155: Regulation setting out the amendments to Decree n. 249 of 10 September 2010 concerning the 'Definition of the regulatory framework, requirements and procedures for initial training of nursery schools, primary, first and second level secondary-school teachers, pursuant to article 2, paragraph 416 of Law n. 244 dated 24 December 2007'.

2013: Departmental Decree (MIUR - Department of Education) 22 November, n. 45: Activation of special qualifying courses.

2014: Ministerial Decree (MIUR) 16 May, n. 312.

2014: Ministerial Decree (MIUR) 20 June, n. 487.

2015: Law 13 July, n.107. In: Gazzetta ufficiale della Repubblica italiana, 15 July 2015, n. 162: 'Reform of the national education and training system and authorisation for the reorganisation of the legislative provisions in force'.

2017: Legislative Decree 13 April, n. 59. In: Gazzetta ufficiale della Repubblica italiana, 16 May 2017, n. 112, Suppl. n. 23/L: 'Reorganisation, adjustment and simplification of the system of initial training and of access for teachers in secondary schools in order to render it functional to the social and cultural valorisation of the teaching profession, pursuant to article 1, paragraphs 180 and 181, letter b) of Law n. 107 of 13 July 2015'.

2017: Ministerial Decree (MIUR) 10 August, n. 616: 'Methods of acquiring university an academic credits'.

2018: Law 30 December, n. 145. In: Gazzetta ufficiale della Repubblica italiana, 31 December 2018, n. 302, Suppl. n. 62/L: 'State budget forecast for the 2019 financial year and multi-year budget for the 2019-2021 period'.

2019: Decree Law 29 October, n. 126. In: Gazzetta ufficiale della Repubblica italiana, 30 October 2019, n. 255: 'Extraordinary and urgent measures concerning the recruitment of academic personnel and research institutions and the qualification of teachers'.

\section{Literature}

Ardizzone, Paolo/Pippolo Lorena (2003): Il Laboratorio di Didattica generale e il sistema di Valutazione della SSIS dell'università Cattolica. In: TD Tecnologie Didattiche 29, 2, pp. 48-54.

Baldacci, Massimo (ed.) (2013): La formazione dei docenti in Europa. Milano.

Balduzzi, Lucia/Vannini, Ira (eds.) (2008): Nuovi insegnanti per una scuola nuova? Un'indagine tra i docenti formati alla Scuola di Specializzazione all'Insegnamento Secondario (SSIS) dell'Università di Bologna. Bologna.

Barbieri, Nicola S./Gaudio, Angelo/Zago, Giuseppe (eds.) (2016): Manuale di educazione comparata. Insegnare in Europa e nel mondo. Brescia.

Becchi, Egle/Ferrari, Monica (eds.) (2009): Formare alle professioni. Sacerdoti, principi, educatori. Milano.

Becchi, Egle/Ferrari, Monica (2018): Diventare professionisti. Un itinerario di ricerca. In: Annali di storia dell'educazione e delle istituzioni scolastiche 25, pp. 229-242.

Bellatalla, Luciana (ed.) (2005): La SSIS a Ferrara tra didattica e ricerca. Tirrenia.

Bondioli, Anna/Ferrari, Monica/Marsilio, Marina/Tacchini, Isabella (eds.) (2006): I saperi del tirocinio. Formare gli insegnanti nelle SSIS. Milano.

Bonetta, Gaetano/Luzzatto, Giunio/Michelini, Marisa/Pieri, Maria Teresa (eds.) (2002): Università e formazione degli insegnanti: non si parte da zero. Udine.

Brocca, Beniamino (2003): Manifesto della riforma: per la modernizzazione dell'istruzione e della formazione. Mogliano Veneto.

Bruscagli, Riccardo/Coppini Beatrice (eds.) (2004): Formazione e aggiornamento dell'insegnante di italiano. Pisa.

Bruschi, Max (2016): Il concorso a cattedra 2016. Innovazioni, prospettive, nodi giuridici. In: Nuova secondaria 7 , pp. 1-6.

Cappa, Carlo/Niceforo, Orazio/Palomba, Donatella (2013): La formazione iniziale degli insegnanti in Italia. In: Revista Española de Educación Comparada 22, pp.139-163.

Capperucci, Davide (2013): La Scuola in Europa. Politiche e interventi dell'Unione europea in materia di istruzione e formazione. Milano.

Cavalli, Alessandro (ed.) (1992): Insegnare oggi. Prima indagine IARD sulle condizioni di vita e di lavoro nella scuola italiana. Bologna. 
Cavalli, Alessandro (ed.) (2000): Gli insegnanti nella scuola che cambia. Seconda indagine IARD sulle condizioni di vita e di lavoro nella scuola italiana. Bologna.

Cavalli, Alessandro/Argentin, Gianluca (eds.) (2010): Gli insegnanti italiani: come cambia il modo di fare scuola. Terza indagine dell'Istituto IARD sulle condizioni di vita e di lavoro nella scuola italiana. Bologna.

Delfrati, Carlo (ed.) (2006): Musica e formazione iniziale. Per una nuova figura professionale in ambito musicale. Milano.

Di Pasqua, Salvatore/Grassilli, Bianca/Storti, Anna (eds.) (2008): La SSIS di Trieste si racconta. Esperienze e riflessioni intorno a una Scuola. Trieste.

Di Pasqua, Salvatore/Grassilli, Bianca/Storti, Anna (eds.) (2009): L'eredità della SSIS. "Luci e ombre" della Scuola per la formazione degli insegnanti: Atti degli incontri di Trieste e di Bologna, novembre 2008. Trieste.

Domenici, Gaetano (ed.) (2017): La formazione iniziale e in servizio degli insegnanti. Roma.

Falanga, Mario (2017): Diritto scolastico. Analisi e profili. Brescia.

Ferrari, Monica (ed.) (2003): Insegnare riflettendo. Proposte pedagogiche per i docenti della secondaria. Milano.

Ferrari, Monica (ed.) (2011): VAL-SILSIS (PV). Strumenti di VALutazione elaborati dalla SILSIS- sezione di Pavia. Pavia.

Ferrari, Monica/Morandi, Matteo (2015): I programmi scolastici di 'educazione fisica' in Italia. Una lettura storico-pedagogica. Milano.

Ferrari, Monica/Morandi, Matteo/Falanga, Mario (2018): Valutazione scolastica. Il concetto, la storia, la norma. Brescia.

Festi, Davide/Malatesta, Maria (eds.) (2010): Università e professioni. Formazione, saperi e professioni per un nuovo millennio. Bologna.

Frabboni, Franco/Giovannini, Maria Lucia (eds.) (2009): Professione insegnante. Un concerto a più voci in onore di un mestiere difficile. Milano.

Genovese, Lucia (2001): Il tirocinio. Progetto, attuazione, monitoraggio, SSIS. Scuola di Specializzazione all'Insegnamento Secondario "Raffaele Laporta". Chieti.

Ghizzoni, Manuela (2017): Le ragioni di una riforma: il nuovo modello di formazione iniziale e accesso al ruolo dei docenti di scuola secondaria. In: Domenici, Gaetano (ed.): La formazione iniziale e in servizio degli insegnanti. Roma, pp. 33-49.

Gibelli, Antonio (2016): La scuola come maneggio del sistema: breve storia di un manifesto antiautoritario. Genova.

Goleman, Daniel/Senge, Peter (2014): The Triple Focus: A New Approach to Education. Florence, MA, it. transl.: (2016): A Scuola di futuro. Manifesto per una nuova educazione. Milano.

Guglielmi, Dina/Guerra, Luigi (eds.) (2016): La formazione iniziale degli insegnanti. Un’indagine sul TFA a Bologna. Milano.

Jori, Maria Luisa/Migliore, Antonietta (2001): Imparare a insegnare. I ferri del mestiere. Milano.

Lisimberti, Cristina (2006): L'identità professionale come progetto. Una ricerca su insegnanti e formazione. Milano.

Luzzatto, Giunio (2001): Insegnare a insegnare. I nuovi corsi universitari per la formazione dei docenti. Roma.

Magni, Francesco (2018). La sfida del "caso" Inghilterra. Formazione iniziale e reclutamento dei docenti. Roma.

Malatesta, Maria (ed.) (2009): Atlante delle professioni, Bologna.

Marescotti, Elena (2009): LA SSIS, ovvero la formazione universitaria dei docenti in Italia (1999-2008). In: Ricerche pedagogiche 43, 172-173, pp. 71-88.

Mattioli, Alessandro (ed.) (2009): Il mestiere di insegnare. Diversi modi di interpretare la formazione dell'insegnante nella scuola superiore. Milano.

Matucci, Giuditta/Rigano, Francesco (eds.) (2016): Costituzione e istruzione. Milano.

Montuschi, Ferdinando (2003): La formazione iniziale per la scuola secondaria. In: Annali dell'Istruzione, 1-2, La formazione degli insegnanti nella scuola della riforma, pp. 57-61.

Morandi, Matteo (2014): La scuola secondaria in Italia. Ordinamento e programmi dal 1859 ad oggi. Milano.

Morin, Edgar (2014): Enseigner à vivre. Arles-Paris, it. transl. (2015): Insegnare a vivere. Manifesto per cambiare l'educazione. Milano.

Perrotta, Romolo (2002): Manifesto degli studenti e dei docenti. La rivoluzione della secondaria superiore. Roma.

Ricuperati, Giuseppe (2015): Storia della scuola in Italia. Dall'Unità a oggi. Brescia.

Robinson, Ken/Aronica, Lou (2015): Creative Schools. The Grassroots Revolution that's Transforming Education. New York, it. transl. (2016): Scuola creativa. Manifesto per una nuova educazione. Trento.

Rostagno, Remo (2014): Manifesto per una rivoluzione della scuola. Villorba.

Saltari, Lorenzo (2014): La formazione e il reclutamento degli Insegnanti in Italia. In: Rivista trimestrale di diritto pubblico 64, 2, pp. 445-475. 
Santoni Rugiu, Antonio/Santamaita, Saverio (2011): Il professore nella scuola italiana dall'Ottocento a oggi. RomaBari.

Schön, Donald A. (1983): The Reflective Practitioner. How Professionals Think in Action. New York - it. transl. (1993): Il professionista riflessivo. Per una nuova epistemologia della pratica professionale. Bari.

Schön, Donald A. (1987): Educating the Reflective Practitioner. Toward a New Design for Teaching and Learning in the Professions. San Francisco - it. transl. (2006): Formare il professionista riflessivo. Per una nuova prospettiva della formazione e dell'apprendimento nelle professioni. Milano.

Striano, Maura (2001): La razionalità riflessiva nell'agire educativo. Napoli.

Ulivieri, Simonetta (2012): Corsi e ricorsi nella formazione degli insegnanti della Scuola Secondaria. Dalla SSIS al TFA. In: Ulivieri, Simonetta (ed.): Insegnare nella scuola secondaria. Per una declinazione della professionalità docente. Pisa, pp.13-43.

Ulivieri, Simonetta/Giudizi, Gloria/Gavazzi, Sandra (eds.) (2002): Dal banco alla cattedra. Didattica e tirocinio formativo per l'insegnamento nella scuola secondaria. Pisa. 